\title{
KELIONIŲ AGENTŪRŲ VERSLO RINKOS KAITOS VEIKSNIAI LIETUVOJE
}

\author{
Aušrinė Armaitienė, Daumantas Bočkus \\ Klaipédos universitetas
}

\begin{abstract}
Anotacija
Straipsnyje analizuojami kelionių agentūrų verslo rinkos kaitos veiksniai Lietuvoje. Kelionių agentūros ir organizatoriai yra svarbi turizmo sektoriaus dalis, kuri apima visas turizmo funkcijas, formas ir atskleidžia šio sektoriaus tendencijas. Kelionių agentūrų verslas yra veikiamas išorès ir vidaus rinkos kaitos veiksnių. İvade keliama problema, kad kelionių agentūrų darbo sąlygos tampa vis sudètingesnès. Kelionių agentūrų rinką labiausiai paveikè du išorès veiksniai: internetas ir naujosios informacinès technologijos bei keleivinio oro transporto dereguliacija. Straipsnyje pateikiami vidiniai kelionių agentūrų rinkos kaitos veiksniai, analizuojami patiriami iššūkiai, nustatomas jų poveikis ir analizuojamas vadybinis atsakas, galintis padèti kelionių agentūroms išlikti šiame versle.

PAGRINDINIAI ŽODŽIAI: kelionių agentūrų rinka, rinkos kaitos veiksniai, informacinès technologijos, dereguliacija.
\end{abstract}

\begin{abstract}
This article analyses business market change factors of travel agencies in Lithuania. Travel agencies and organizers represent an important part of tourism sector, which includes all functions and forms of tourism as well as reflects the trends of this industry. Travel agency business is affected by intense external and internal market change factors. The problem of the research raised in the introduction is that business conditions of the travel agencies are getting complicated. There are two principal external factors that made the most significant impact on travel agency market: internet with new information technologies and deregulation of passenger air transport. The article identifies internal change factors of travel agency business market, analyses emerging challenges and their impact, and the managerial response is analysed which would help travel agencies survive in this business.

KEY WORDS: travel agency market, market change factors, information technologies, deregulation.
\end{abstract}

DOI: http://dx.doi.org/10.15181/tbb.v73i1.1264

\section{Ivadas}

Turizmas yra viena didžiausių privataus sektoriaus industrijų, kurio augimas, ekonominis reikšmingumas ir potencialas ryškūs visame pasaulyje (Dixit, Belwal, Singh, 2006). Lietuva priklauso susiklosčiusiai, tačiau permanentinius pokyčius dèl rinkų liberalizavimo, klimato kaitos, ekonominių krizių galingos konkurencijos sąlygomis patiriančiai Europos šalių turizmo rinkai. Šios sąlygos veikia ne tik makroaplinką (Armaitienè, Bertužytė, 2014).

Kelionių agentūros ir organizatoriai yra viena iš šešių turizmo sektoriaus sudètinių dalių, kuri apima visas turizmo funkcijas, formas ir produktus bei atskleidžia šio sektoriaus tendencijas. Lietuvoje turizmo sektorius yra viena didžiausią po- 
tencialą augti turinti industrija, kurios plètra yra geras bendro šalies ekonominio augimo rodiklis (Subačienè, Senkus, 2013). Remiantis ūkio ministerijos duomenimis, $2013 \mathrm{~m}$. turizmo sektoriaus dalis bendroje BVP suvestineje sudare $3 \%$, tačiau Pasaulio turizmo ir kelionių tarybos skaičiavimais, ịvertinus ir netiesioginę šio sektoriaus įtaką, jis Lietuvoje sukuria iki 4,8 proc. BVP. Turizmui būdinga veikla užsiima apie 41,1 tūkst. žmonių, arba 4,4 proc. samdomų šalies darbuotojų (Lietuvos ekonomikos apžvalga, 2015).

Lietuvos turizmo departamento duomenimis, pastaruosius kelerius metus atvykstamuoju ir išvykstamuoju turizmu užsiimančių kelionių agentūrų skaičius išlieka stabilus: $2011 \mathrm{~m}$. veikè 262 išvykstamojo turizmo kelionių agentūros ir organizatoriai, 2012 m. - 248 ịmonès, 2013 m. - 227 ir 2014 m. - 250 ịmonių. Tendencija dèl atvykstamojo turizmo įmonių panaši; nuo 2011 iki 2013 m. šių imonių skaičius sumažèjo nuo 104 iki 95, nuo 2014 m. pakilo iki 114 įmonių. Lietuvos gyventojų, apsilankiusių užsienyje, ir atvykusių užsieniečių skaičius auga. 2014 m. turistų (išvykusių Lietuvos gyventojų), pasinaudojusių kelionių agentūrų ir kelionių organizatorių paslaugomis, buvo 15,5 proc. daugiau, palyginus su 2013 m. Tačiau 2014 m. turistų (atvykusių užsieniečių), pasinaudojusių kelionių agentūrų ir kelionių organizatorių paslaugomis, skaičius sumažèjo 8,6 proc., palyginus su $2013 \mathrm{~m}$.

Rinkos pokyčiu veiksnių suvokimas yra esminis veiksnys, kelionių agentūroms leidžiantis išlikti versle. Technologinè pažanga ir sparti interneto plètra kelia naujus iššūkius kelionių agentūrų verslo rinkai. Žmonès, planuojantys poilsines ar verslo keliones, vis labiau linksta turizmo paslaugas užsisakyti patys, atsisakydami kelionių agentūrų paslaugų. Tikẻtina, kad kelionių paslaugų užsakymai internetu ir toliau augs kartu su kitų technologijų plètra (Bergin-Seers, O’Mahony, Quiazon, 2007). Išmaniosios kreditinès kortelès ir elektroniniai bilietai - taip pat vieni svarbiausių veiksnių, lemiančių kelionių paslaugų užsakymą internetu.

Akivaizdi ir sparti turizmo sektoriaus plètra sulaukia pelnyto įvairių mokslo tyrinètojų dèmesio. Vis dẻlto kelionių agentūrų verslo rinkos kaitos veiksniai Lietuvoje išsamiai nenagrinèti. Kelionių agentūrų verslo sektorius dažniausiai tyrinejjamas rinkodaros, vartotojų elgsenos tyrimų kontekste, neišryškinant šio sektoriaus rinkos kaitos veiksnių, ypatumų ir tendencijų.

Turizmo sektorius yra labai dinamiškas, reikalaujantis greitos reakcijos ị kintančią rinką. Interneto skvarba, technologijų vystymasis, turizmo verslo modelio kaita bei kiti fundamentalūs turizmo rinkos pokyčiai verčia keistis ir kelionių agentūras. Patiriant daugybę naujų iššūkių, kelionių agentūrų verslo rinkos kaitos veiksnių žinojimas gali būti pagrindinis veiksnys, sėkmingai prisitaikiusioms agentūroms leisiantis išlikti versle. 
Preliminarūs tyrimai rodo, kad kelionių agentūrų darbo sąlygos tampa vis sudètingesnès. Tai gali būti siejama su tam tikrais probleminiais veiksniais: informacinių technologijų plètra, padidejjusi konkurencija, sumažèjusi rinkos dalis ar pelno marža.

Tyrimo tikslas: išanalizuoti Lietuvos kelionių agentūrų verslo rinką veikiančius ir pokyčius lemiančius veiksnius.

Tyrimo objektas - Lietuvos kelionių agentūrų verslo rinkos kaitos veiksnių įtaka kelionių agentūrų verslui Lietuvoje.

Tyrimo tikslui pasiekti iškelti šie tyrimo uždaviniai:

- išanalizuoti kelionių agentūrų verslo rinkos kaitos veiksnius;

- ištirti, kaip interneto plètra paveikè kelionių agentūrų rinką;

- išanalizuoti vadybinị įmonių atsaką ị veiksnių poveikị.

Atliekant tyrimą taikytas kokybiniams tyrimams priskiriamas giluminio interviu metodas. Tyrime dalyvavę ekspertai atrinkti atsižvelgiant ị agentūros dydį. C. Siebenaler ir D. L. Groves straipsnyje "Travel agents and their survival" (2002) pateiktas kelionių agentūrų skirstymas ị keturias grupes: 1) mažos kelionių agentūros su labai ribotais ištekliais; 2) vidutinès, turinčios 2-3 kelionių agentus; 3) didelès agentūros, savo veikloje taikančios aukščiausias technologijas, priklausomos nuo interneto ir operacijų automatizavimo (inovatorès); 4) interneto pagrindu veikiančios kelionių agentūros. Lietuvoje tirti pasirinktos antro ir trečio tipo agentūros. Ekspertais buvo laikomi specialistai, turintys ne mažesnę kaip 5 metų darbo kelionių agentūroje patirtį. Interviu su turizmo ekspertais gauta medžiaga transkribuota ir vèliau analizuota taikant kokybinio tyrimo kriterijus.

\section{Kelionių agentūrų verslo rinkos tyrimų apžvalga ir metodologijos}

Turizmo sektorius ịvardijamas kaip didžiuli potencialą augti turinti industrija, todèl šio sektoriaus plètra sulaukia pelnyto ịvairių mokslo tyrinètojų dèmesio. Analizuojant atliktus kelionių agentūrų verslo rinkos tyrimus pastebėta tendencija, kad didžiausi pokyčiai siejami su informacinių technologijų ir interneto plètra.

T. Vasudavan ir C. Standing moksliniame straipsnyje "The impact of the Internet on the role of travel consultants" (1999) kelia hipotezę, kad interneto ir technologijų plètra gerokai sumažins kelionių agentūrų rinkos dalị. Kelionių agentūru verslo plètros tendencijoms nustatyti sudarytas klausimynas, kuriuo siekta išsiaiškinti kelionių agentų požiūrị ị naująsias technologijas, gebẻjimą prisitaikyti prie pakitusių verslo sąlygų ir kokią vietą rinkoje kelionių agentai tikisi užimti. Iš viso apklausti 102 kelionių agentai. Tyrimo rezultatai atskleide, kad naujosioms technologijoms iggaunant vis didesnę svarbą rinkoje, tradicinių kelionių agentūrų mažès, išliks tik geriausiai prisitaikę prie pakitusių verslo sąlygų. 
Panašų tyrimą savo moksliniame straipsnyje "The impact of the internet on travel agencies" (2004) aprašè R. Law, K. Leung ir J. Wong. Atliekant šị tyrimą apklausti ne kelionių agentai, o turistai. Tyrime dalyvavo 413 turistų. Gauti rezultatai atskleidè, kad žmonès yra vis daugiau linkę naudotis internetinėmis agentūromis ir į̌velgia jose daug privalumų, tačiau tradicinès kelionių agentūros vartotojams vis dar išlieka svarbios, todèl nereikètų tikètis ženklaus agentūrų skaičiaus mažèjimo.

Moksliniame straipsnyje "Travel agency threats and opportunities: the perspective of successful owners" (Lawton, Weaver, 2009) giluminio interviu metodu apklausta 19 išskirtinai sẻkmingai kelionių agentūrų verslą JAV plètojančių savininkų. Atrinktos tik tradicinès agentūros, neitraukiant internetinių agentūrų ir individualiai dirbančių agentų. Atrinktos didžiausią pelną ir jo prieaugị turèjusios agentūros. Atliekant tyrimą atskleista, kad pagrindinè grèsmè kelionių agentūroms kyla iš neigiamo visuomenès požiūrio ị jas, pernelyg didelio pasitikejjimo internetinèmis agentūromis. Tarp grèsmių ịvardyti ir nekvalifikuoti kelionių agentai, neigiamas žiniasklaidos požiūris ị agentūras bei nesugebejjimas pritraukti jaunų darbuotojų.

C. Siebenaler ir D. L. Groves moksliniame straipsnyje "Travel agents and their survival" (2002) aprašo tyrimą, atliktą išanalizavus 4 skirtingų tipų kelionių agentūras, kurias galima suskirstyti $\mathfrak{i}$ šias grupes: 1) mažos ir turinčios ribotus išteklius; 2) vidutinès, turinčios 2-3 kelionių agentus; 3) didelès agentūros, besinaudojančios aukščiausiomis technologijomis, priklausomos nuo interneto ir operacijų automatizavimo; 4) interneto pagrindu veikiančios agentūros. Tirta, kaip šios skirtingų tipų agentūros prisitaikè ir keitėsi pereinamuoju laikotarpiu, kai ịvyko didieji turizmo rinkos pokyčiai, susiję su aviakompanijų sprendimu nemokèti ar sumažinti agentūrų komisinį atlygị už aviabilietų pardavimus bei internetinių kelionių agentūrų atėjimu ị rinką. Atliekant tyrimą taikytas teminis turinio analizès metodas. Analizuoti teminiai straipsniai ir 82 atvejo studijos. Analizuojant atvejo studijas pasitelktas A. Thurston sisteminis vertinimas, kai turizmo industrijos ekspertai vertino paskiru įmonių sèkmę prisitaikant prie pakitusių rinkos sąlygų. Tyrimas atskleidè, kad prie pakitusių kelionių agentūrų verslo rinkos sąlygų prisitaikyta ir vis dar bandoma taikytis. İmonès, nesugebėsiančios prisitaikyti ir išnaudoti e-komercijos teikiamų galimybių, bus priverstos palikti šị verslą.

Moksliniame straipsnyje "The travel agency service industry: industry trends and practices” (Bergin-Seers, O'Mahony, Quiazon, 2007) autoriai tiria kelionių agentūroms tenkančius iššūkius, kurie susiję su besikeičiančiais keliautojų ịpročiais ir interneto skvarba. Nustatyta, kad didžiausi pokyčiai susiję su kelionių rezervavimo modelio ir informacijos paieškos kanalų kaita. Kelionių agentūros gali išlikti rinkoje konkuruodamos su internetiniais užsakymo portalais ne kaina, 
bet kurdamos pridètinę vertę, kai teikiamos suasmenintos ir profesionalios paslaugos. Tyrimas atliktas naudojantis antrinių šaltinių analize.

Kitame moksliniame straipsnyje "Challenges for the survival of travel agencies due to new tendencies on the tourism market" (Stević, Stevic, 2011) autoriai kelia klausimus apie tradicinių kelionių agentūrų galimybes išlikti rinkoje, kai technologijos ir interneto plètra ịgauna vis didesnị pagreitị. Tiriama, ar tiesioginiai užsakymai internetu suteikia pridètinę vertę kelionių operatoriams ir vartotojams. Darbe keliamas tikslas išsiaiškinti kelionių agentūrų plètros tendencijas ir esamą situaciją, kurioje šiuo metu yra kelionių paslaugų pardavimo tarpininkai.

Tyrimas atliktas dviejose šalyse - Portugalijoje, Bosnijoje ir Hercogovinoje. Interviu metodu apklausti skirtingas pozicijas darbe užimantys kelionių agentūrų darbuotojai. Siekiant išsiaiškinti, ar išoriniai veiksniai vienodai veikia dideles ir mažas agentūras, respondentai atrinkti iš skirtingo dydžio įmonių. Papildomai apklausta Portugalijos kelionių agentūrų ir turizmo asociacija.

Gauti tyrimo duomenys atskleidè, kad tiek Portugalijos, tiek Bosnijos ir Hercogovinos kelionių agentūrų darbuotojai neįžvelgia didelès grèsmès bei neigiamų padarinių jų atstovaujamoms agentūros dèl interneto skvarbos. Bosnijoje ir Hercogovinoje, kur internetas nėra plačiai prieinamas daugeliui namų ūkių, ši problema pasirodè dar mažiau aktuali. Pardavimų apimčių mažèjimas labiau siejamas su šalių patiriamomis ekonomikos problemomis.

Vis dèlto visi tyrimo dalyviai sutiko, kad siekiant išlaikyti savo pozicijas rinkoje, būtina diegti naujoves, stebèti rinkos tendencijas, siekti didesnio profesionalumo ir teikti asmeniškesnes paslaugas. Respondentų teigimu, nėra esminio skirtumo tarp didelių ir mažų kelionių agentūrų, siekiančių prisitaikyti prie rinkos kaitos veiksnių, vis délto paminèta, kad didesnès organizacijos turi daugiau galimybių derètis dèl kainų, daugiau finansinių ir žmogiškųų išteklių. Remdamiesi gautais rezultatais, autoriai padarẻ išvadą, kad artimiausiu metu kelionių agentūroms nekyla didesnès grèsmės išnykti, jei tik bus imtasi anksčiau minètų priemonių.

Moksliniame straipsnyje "Population ecology, institutionalism and the internet: Travel agencies evolving into middlemen" (Sor, 2005) analizuojama, kaip didžiuju pokyčių kontekste transformuojasi įmonių organizacinè struktūra. Apklaustos Australijoje veikiančios kelioniu agentūros, kur interviu metodu surinkta informacija. Tirta, kada kelionių agentai pradejjo keisti savo veiklos strategiją reaguodami ị interneto plètrą, kokie sprendimai buvo priimti, kodèl pasirinkti atitinkami sprendimai, kurie iš jų pasiteisino ir kuriuo keliu pasuko kelionių agentūros. Visi šie klausimai tirti per gyventojų ekologijos ir institucionalizmo paradigminę filtrų prizmę. Nustatyta, kad pokyčiai makroaplinkoje tiesiogiai veikia mažas organizacijas, kurios yra priverstos keistis. Interneto plètra lėmè, kad seniau galioję veikimo būdai ir taisyklès šiandien nebetinka, todèl turi būti kuriamos naujos veiklos 
strategijos. Pasikeitusios sąlygos nustato sąlygas, prie kurių organizacijos turi prisitaikyti.

R. Law, R. Leung ir D. Buhalis (2009) moksliniame straipsnyje "Information Technology Applications in Hospitality and Tourism: a Review of Publications from 2005 to 2007" pateikia informacinių technologijų (IT) svarbos sèkmingai kelionių agentūrų veiklai užtikrinti tyrimo rezultatus. Pasirinktas turinio analizės metodas, kurị taikant išanalizuota 215 straipsnių, susijusių su IT turizmo ir kelionių agentūrų versle. Straipsniai suskirstyti ị tris kategorijas, susijusias su vartotojais, technologijų plètra ir tiekejjais. Ištyrę visus straipsnius autoriai padarè išvadą, kad IT vis svarbesnès kelionių agentūrų versle, nes padeda mažinti darbo sąnaudas, didinti darbo efektyvumą ir gerinti teikiamų paslaugų kokybę. Teigiama, kad ne visos agentūros jau spejjo ịvertinti informacinių technologijų svarbą ir neskiria tam pakankamai dèmesio, dèl ko vèliau gali patirti nuostolių konkurencinèje kovoje su kitomis agentūromis.

Kelionių agentūrų plètros tendencijas ir rinkos sąlygų pokyčius, kurie skatina adaptavimosi ir keitimosi procesus, savo moksliniuose straipsniuose analizuoja keletas kitų mokslininkų: T. Mayr, A. Zins (2009), M. Dixit, R. Belwal, G. Singh (2006), J. Costa (1995), P. Dodu Silvia (2008).

Analizuojant atliktus tyrimus pastebèta tendencija, kad 1999-2014 m. laikotarpio pradžioje daugiausia tirtas vartotojų požiūris ị naująsias technologijas, personalo gebejjimą adaptuotis prie besikeičiančių verslo sąlygų, įmonių valdymo strategijų kaitos galimybes, vèliau tyrimo objektas kito, pereita prie rezervavimo modelio ir informacijos paieškos kanalų kaitos, immonių vadybos modelių kaitos analizès. Atlikta straipsnių analizė leidžia teigti, kad 1999-2014 m. vyko ryškūs pokyčiai kelionių agentūrų verslo rinkoje. Nors šiuo laikotarpiu analizuoti panašūs veiksniai, jų poveikio aspektai kito. Atliktuose tyrimuose analizuota makroaplinkos ịtaka mažoms kelionių agentūroms, interneto ir informacinių technologijų plètros padariniai, rinkos sistemos kaita, kai tarpininkams nebemokamas komisinis mokestis, agentūros išstumiamos iš tarpininkų grandies, pigių skrydžių kompanijos veikia agentūrų rinką, neigiamas žiniasklaidos požiūris.

Straipsnių analizè atskleidžia, kad kelionių agentūrų verslo ir vadybos tyrimų autoriai taikè tradicinius sociologinius metodus: interviu ir ekspertinị vertinimą, anketinę apklausą, turinio analizę bei atvejo studijas.

\section{Lietuvos kelionių agentūrų ekspertinio tyrimo rezultatai}

2015 m. atlikus Lietuvos kelionių agentūrų ekspertinị tyrimą paaiškejjo, kad kelionių agentūras veikia rinkos kaitos veiksniai, todẻl kyla sudètingų iššūkių. 
Kaip vieną rimčiausių iššūkių informantai ịvardija internetą ir naująsias informacines technologijas. Didžiausia grèsmė tradicinėms kelionių agentūroms kyla tiekejjams perejjus prie tiesioginių pardavimų, taip iš agentūrų atimant tarpininkų vaidmeni.

Vartotojų elgsenos pokyčiai, kai vis daugiau žmonių internetu užsisako turizmo paslaugas, taip pat įvardijama kaip rimta grèsmè. Vidutinių ir didžiujų agentūrų informantų teigimu, tiekejjai, naudodami ịvairias rinkodaros priemones ir naująsias informacines technologijas, formuoja viešają nuomonę ir ịpročius, taip sukeldami ryškius vartotojų elgsenos pokyčius. Turizmo ekspertų teigimu, interneto ir technologiju plètra paskatino tiekèjus daugiau dèmesio skirti tiesioginiams pardavimams. Skatindami tiesioginius pardavimus tiekejjai daug investavo ị rinkodarą, technologijų ir ịvairių rezervavimo sistemų tobulinimą. Šie veiksmai sietini su reikšmingais vartotojų elgsenos pokyčiais užsakant turizmo produktus ir paslaugas (1 lentelè).

1 lentele. Interneto įtaka kelionių agentūroms

Table 1. Impact of internet on travel agencies

\begin{tabular}{|c|c|c|}
\hline Kategorija & Subkategorija & Patvirtinantis teiginys \\
\hline \multirow[t]{2}{*}{ Interneto itaka } & $\begin{array}{l}\text { Vartotojų } \\
\text { elgsenos } \\
\text { pokyčiai }\end{array}$ & $\begin{array}{l}\text { „Kitas faktorius, susijęs su internetu, yra tai, kad yra } \\
\text { užaugusi ta karta, kuri jau puikiai geba naudotis internetu } \\
\text { ir didelei daliai tų žmonių patinka būti savarankiškiems } \\
\text { ir viską užsisakyti patiems“. } \\
\text { „Žmonės patys daug perka internetu, daug visko } \\
\text { susiranda, apie } 30 \text { proc. rinkos praktiškai prapuolè iš tų, } \\
\text { kurie pirkdavo „Novaturo“, „,Tezturo“ keliones“. } \\
\text { „Sakyčiau, užaugo nauja karta, jaunimas, kuriems augant } \\
\text { kartu su interneto plètra susiformavo nauji ipročiai, } \\
\text { gyvenimo būdas ir gebejjimai, kai pirkimas internetu } \\
\text { tampa savirealizacijos, mados ir garbės reikalu“. }\end{array}$ \\
\hline & $\begin{array}{l}\text { Tarpininkų } \\
\text { vaidmens } \\
\text { mažèjimas }\end{array}$ & $\begin{array}{l}\text { „Kelionių organizatoriai pereina ị tiesioginius pardavi- } \\
\text { mus ir taip apeina kelionių agentūras““. } \\
\text { „Aviakompanijos taikosi ị verslą, kuria ịmonèms pritai- } \\
\text { kytus produktus - specialias rezervacines sistemas, nuo- } \\
\text { laidas bilietams, visokias lojalumo programas“. }\end{array}$ \\
\hline
\end{tabular}

Kitas svarbus iššūkis kelionių agentūroms yra rinkos dalyvių konkurencija, kurią galima suskirstyti ị konkurenciją su tradicinėmis ir interneto pagrindu veikiančiomis agentūromis. Rinkoje paplitęs didelių nuolaidų taikymas standartiniams kelionių paketams atima reikšmingą dalị pelno, todẻl mažosioms agentūroms, kurių pagrindinė veikla yra tokių kelionių paketų pardavimas, vis sunkiau išlikti. 
Daugelis informantų minejjo kvalifikuoto personalo problemą. Turizmo ekspertų teigimu, rinkoje nepakanka kvalifikuotų darbuotojų, atrasti naujų darbinès patirties neturinčių specialistų nesudètinga, tačiau kvalifikuoti darbuotojai daugeliui agentūrų yra aktuali problema.

Kalbèdami apie kelionių agentūrų patiriamus iššūkius daugelis informantų mini neigiamą kelionių agentūrų ịvaizdį. Išanalizavus turizmo ekspertų atsakymus, galima teigti, kad didžiausią įtaką tam daro kelionių agentūrų ir tiekèjų bankroto atvejai, nes visuomenèje tai sukelia didelị atgarsị.

2 lentelè. Neigiamas kelionių agentūrų ịvaizdis

Table 2. Negative image of travel agencies

\begin{tabular}{|c|c|c|}
\hline Kategorija & Subkategorija & Patvirtinantis teiginys \\
\hline \multirow[t]{3}{*}{$\begin{array}{l}\text { Neigiamas } \\
\text { ivvaizdis }\end{array}$} & Bankrotai & $\begin{array}{l}\text { „Taip pat didelè dalis klientų jaučia nesaugumo jausmą } \\
\text { dèl dažnai kelionių agentūras, organizatorius ištinkančių } \\
\text { bankrotų“. }\end{array}$ \\
\hline & Kainos & $\begin{array}{l}\text { „Žmonès mano, kad kelionių agentūra jiems nereikalinga. } \\
\text { Visi sako, kad imame per didelius pinigus - aptarnavimo } \\
\text { mokesčius ir taip klientai be reikalo praranda pinigus“. } \\
\text { „Visi galvoja, kad internete gaus pigiau, bet toks požiūris ne } \\
\text { visada atitinka realybę“. }\end{array}$ \\
\hline & Niveliacija & $\begin{array}{l}\text { „Neigiamas požiūris i agentūras taip pat yra dèl jų } \\
\text { šabloniškumo, individualumo trūkumo, nes iš esmès visos } \\
\text { siūlo praktiškai vienodus produktus, turi beveik tuos pačius } \\
\text { partnerius užsienio šalyse“. } \\
\text { „Klientas nemato jokių privalumų, jis supranta, kad visur } \\
\text { jam pasiūlys plius minus tą patị"“. }\end{array}$ \\
\hline
\end{tabular}

Neigiamą kelionių agentūrų ịvaizdị formuoja ir intensyvios internetinių portalų rinkodaros kampanijos, kai teigiama, kad internetu užsisakyti kelionę pigiau. Kelionių agentūrų menkas išskirtinumas, paslaugų niveliacija ịvardijami kaip dar vienas veiksnys, prisidedantis prie neigiamo ịvaizdžio formavimo. Informantų teigimu, klientai ne visada pastebi pridètinę vertę, kurią agentūros jiems galètų suteikti lyginant su internetiniais turizmo paslaugų užsakymo portalais.

Geopolitine situacija, teroristiniai išpuoliai, politinio režimo pasikeitimai, nestabili politinè ir finansinè turistus priimančių šalių padètis sukelia daug problemų tiek kelionių agentūroms, tiek bendrai visai turizmo rinkai. Informantų teigimu, lieka mažiau krypčių, kurias būtų galima klientams pasiūlyti, jie mažiau keliauja ir yra linkę atšaukti jau užsakytas keliones.

Apibendrinus turizmo ekspertų įžvalgas apie interneto plètros poveikị kelionių agentūroms, galima teigti, kad internetas panašiai veikia visas agentūras: mažèja 
klientų skaičius, nes dalis jų paslaugas užsisako internetu, mažèja agentūrų pelno marža, nes intensyviai konkuruojama su tradicinėmis ir interneto pagrindu veikiančiomis kelionių agentūromis.

Kalbėdami apie teigiamą interneto plètros poveikị informantai mini, kad internetas yra puiki pagalbinė priemone igyvendinti ịvairias rinkodaros strategijas, tačiau tai reikalauja didelių žmogiškujų, finansinių išteklių ir sistemingo darbo.

3 lentele. Interneto plètros poveikis klientų skaičiui, pelnui ir rinkodaros priemonių igyvendinimui

Table 3. Impact of internet on customers' number, profit and implementation of marketing tools

\begin{tabular}{|c|c|c|}
\hline Kategorija & Subkategorija & Patvirtinantis teiginys \\
\hline $\begin{array}{l}\text { Klientu } \\
\text { skaičius }\end{array}$ & Mažèjimas & $\begin{array}{l}\text { „Klientų srauto atžvilgiu galima matyti dalini } \\
\text { sumažejimą. Yra nemaža dalis žmonių, kurie vieną kitą } \\
\text { kartą pasinaudoję agentūros paslaugomis, vėliau nutaria, } \\
\text { kad jiems naudingiau viską užsisakyti patiems“. } \\
\text { „Standartinių kelionių paketų pardavimas bei nesudètingų } \\
\text { maršrutų aviabilietų pirkimas stipriai sumažejo, nes } \\
\text { žmogus labai paprastai viską gali nusipirkti pats. Tas } \\
\text { mastas auga su žmonių patyrimu ir suvokimu apie } \\
\text { turizmo produktus ir kainas“. }\end{array}$ \\
\hline \multicolumn{2}{|l|}{ Pelno marža } & $\begin{array}{l}\text { „...siekdami konkuruoti su internetu privalome taikyti } \\
\text { nuolaidas kelionėms, mažinti aptarnavimo mokesčius“. } \\
\text { „Dèl interneto buvome priversti susimažinti savo pelno } \\
\text { maržą, nes privalome konkuruoti ne tik su kitomis } \\
\text { agentūromis, tačiau ir internetiniais turizmo paslaugu } \\
\text { užsakymais. } \\
\text { Organizuojant keliones iš atskirų komponentų } \\
\text { (skrydis, viešbutis, pervežimas) privalome taikyti } \\
\text { minimalų aptarnavimo mokesti,, nes visos kainos yra } \\
\text { viešai prieinamos internete ir klientams, todè jie gali } \\
\text { pasitikrinti kainas“. }\end{array}$ \\
\hline Rinkodara & $\begin{array}{l}\text { Internetinė } \\
\text { reklama }\end{array}$ & $\begin{array}{l}\text { „Internetinis puslapis gali būti sėkmingai išnaudojamas } \\
\text { pristatyti save klientams“. } \\
\text { „Taip pat praradom potencialius klientus, kurie ipprastai } \\
\text { galbūt būtų užèję i mūsų agentūrą, bet dèl aktyvaus } \\
\text { internetinių portalų marketingo net nesikreipe į mus“. }\end{array}$ \\
\hline
\end{tabular}

Interneto plètra paskatino interneto pagrindu kuriamų technologijų ir programų vystymąsi, kurios gerokai praplètè kelionių agentūrų galimybes užsakant skirtingas turizmo paslaugas ir produktus, padidino paslaugų prieinamumą. Ekspertų teigimu, supaprasteję techniniai procesai agentūroms taip pat sutaupo laiko ir lèšų, paprastina bendravimą su klientais. 
Dauguma informantų pastebi, kad interneto plètra padarè įtaką darbuotojų darbo pobūdžiui. Didelis informacijos srautas ir nuolat besikeičianti aplinka verčia darbuotoją dirbti dinamiškai, greitai susirasti informaciją ir ją susisteminti. Darbo pobūdis iš dalies keitèsi, nes nesudètingus užsakymus, kuriems nereikia išskirtinės kvalifikacijos, klientai linkę atlikti patys, ị agentūras kreipiasi dèl sudètingesnių paslaugų užsakymo.

Kalbėdami apie galimybę sėkmingai konkuruoti su internetiniais turizmo paslaugų užsakymo portalais dauguma turizmo ekspertų mini būtinybę investuoti ị personalo kvalifikacijos kèlimą, internetinị puslapị, socialinius tinklus ir naująsias technologijas. Informantų nuomone, agentūroms būtina sudaryti galimybę jų paslaugas užsakyti internetu. Lokacija prekybos centruose ir kitose vietose, kurios pritraukia didelius žmonių srautus, yra veiksmingas būdas sulaukti daugiau klientų. Ekspertų teigimu, kelionių agentūroms didelę pridètinę vertę kuria papildomos, unikalios paslaugos ar specializacija tam tikroje srityje. Kaip alternatyvą ir galimybę amortizuoti mažèjančius privačių klientų srautus dauguma turizmo ekspertų ịvardijo paslaugų teikimo orientavimą ị verslo segmentą, kuriam bendradarbiavimas su agentūromis vis dar išlieka naudingas.

Išanalizavus turizmo ekspertų pateiktus atsakymus pastebèta, kad siekiant išlaikyti ar padidinti įmonès konkurencingumą daugelis agentūrų èmèsi panašių veiksmų. Vadybos praktikos požiūriu, siekdamos veiksmingai konkuruoti daugelis agentūrų klientams suteikia galimybę susisiekti nedarbo valandomis, investuoja ị personalo kvalifikacijos kèlimą, užtikrina tinkamą darbuotojų skaičių. Agentūros investuoja ị savo internetinio puslapio dizainą, funkcionalumą, kuria unikalų turinị, tačiau ne visos jos turi aiškią viziją ir strategiją šiuo požiūriu. Investuojama $\mathfrak{i}$ technologijas, rezervacines sistemas, tačiau ne visos agentūros tam skiria didelị dèmesị. Su socialiniais tinklais dirba visos informantų atstovaujamos agentūros, bet trūksta nuoseklumo, be to, reikia turèti aiškią viziją. Atsižvelgdamos ị rinkos poreikius agentūros plečia paslaugų spektrą. Tik trys agentūros sistemingai dirba ieškodamos naujų verslo klientų, dalyvaudamos viešuosiuose pirkimuose. Mažą šią nišą išnaudojančių agentūrų skaičių būtų galima paaiškinti tuo, kad daugeliui jų trūksta technologinių, finansinių ir žmogiškujų išteklių, kad galètų užsiimti šia veikla.

Turizmo ekspertai ịžvelgia keletą reikšmingų kelionių agentūrų pranašumų, lyginant su internetiniais turizmo paslaugų užsakymo portalais (4 lentelè). 
4 lentelè. Tradicinių kelionių agentūrų pranašumai, lyginant su internetiniais užsakymo portalais

Table 4. Advantages of conventional travel agencies over the online booking websites

\begin{tabular}{|c|c|c|}
\hline Kategorija & Subkategorija & Patvirtinantis teiginys \\
\hline \multicolumn{2}{|l|}{ Kaina } & $\begin{array}{l}\text { „Aviabilietus taip pat galime pasiūlyti geresne kaina, } \\
\text { nes kol kas internetinės bilietų rezervavimo sistemos ne } \\
\text { visada veikia tobulai, todèl ne visos kainos yra pateikia- } \\
\text { mos“. } \\
\text { „Yra tokių kainų kvotavimo ir maršruto sudèliojimo } \\
\text { subtilybių, kur pasiekiamas kainos ir patogumo lygis, } \\
\text { kurių žmogus be patirties internete vargiai ar rastų“. }\end{array}$ \\
\hline \multirow[t]{2}{*}{$\begin{array}{l}\text { Apmokèjimo } \\
\text { sąlygos }\end{array}$} & $\begin{array}{l}\text { Mokejjimo } \\
\text { atidejjimas }\end{array}$ & $\begin{array}{l}\text { „Taip pat verslo klientams, su kuriais dirbame pagal } \\
\text { sutartis, bei lojaliems privatiems klientams galime } \\
\text { pasiūlyti kelių dienų mokèjimo atidèjimą،. }\end{array}$ \\
\hline & $\begin{array}{l}\text { Atsiskaitymo } \\
\text { būdai }\end{array}$ & $\begin{array}{l}\text { „Daugybė klientų nori atsiskaityti grynais, nes kortele } \\
\text { nemoka ar neturi tokios, kuri būtų tinkama, arba nenori, } \\
\text { kad mokesčiai tuos pirkinius matytų“. }\end{array}$ \\
\hline \multicolumn{2}{|c|}{ Paslaugų pasirinkimas } & $\begin{array}{l}\text { „Turim tokias viešbučių rezervavimo sistemas, kuriose } \\
\text { viešbučių pasirinkimas ir kainos neretai didesnès, nei } \\
\text { klientas galètų rasti pats internete“. } \\
\text { „Taip pat dažnai galime pasiūlyti daugiau produktų ir } \\
\text { variantų, nei žmogus rastų internete“. }\end{array}$ \\
\hline \multicolumn{2}{|c|}{ Techninės galimybės } & 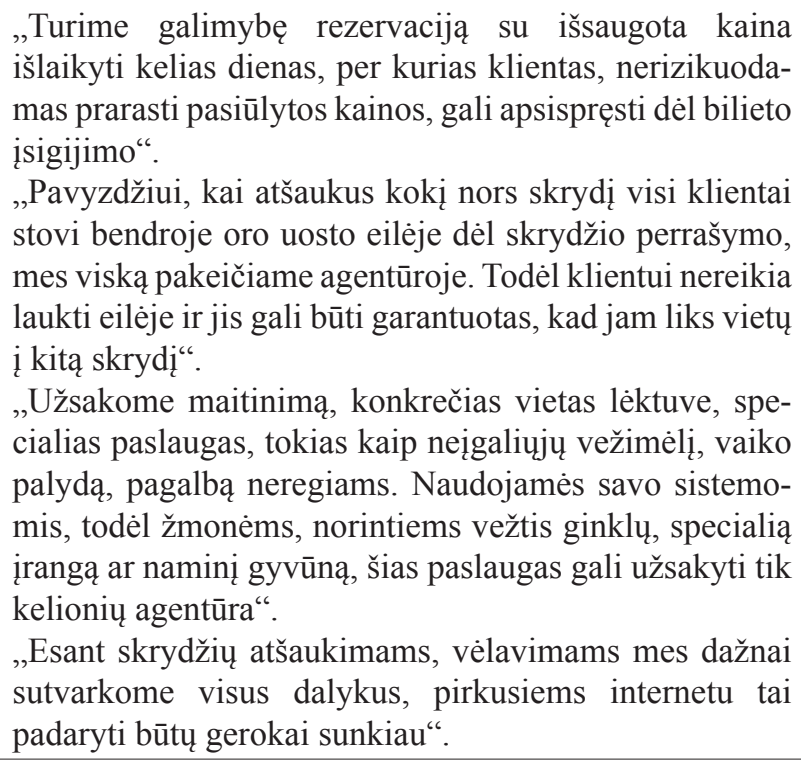 \\
\hline
\end{tabular}




\begin{tabular}{|c|c|c|}
\hline Kategorija & Subkategorija & Patvirtinantis teiginys \\
\hline \multirow[t]{3}{*}{$\begin{array}{l}\text { Žmogiškasis } \\
\text { veiksnys }\end{array}$} & $\begin{array}{l}\text { Tiesioginis } \\
\text { bendravimas }\end{array}$ & $\begin{array}{l}\text { „Yra klientų, kurie būna prisiskaitę atsiliepimų apie } \\
\text { kokį viešbutị, bet nepasitiki jais, o kai pasakai, kad pats } \\
\text { esi ten buvęs, tai jiems padaro įspūdị“. }\end{array}$ \\
\hline & $\begin{array}{l}\text { Laiko } \\
\text { sutaupymas }\end{array}$ & $\begin{array}{l}\text { „Kai nežinai, kaip ir kur ieškoti, gali vargti labai ilgai } \\
\text { su tuo, o mūsų klientai pasako, ko nori, ir mes viską } \\
\text { jiems suieškom, aišku, kiti bijo aptarnavimo mokesčio, } \\
\text { bet ar verta kelias dienas pačiam ieškot, jei nuturi laiko } \\
\text { vien tam, kad kelis eurus sutaupytum?“. }\end{array}$ \\
\hline & $\begin{array}{l}\text { Profesionali } \\
\text { konsultacija ir } \\
\text { pagalba }\end{array}$ & $\begin{array}{l}\text { „Ne visi net žino, kad registraciją reikia pasidaryti } \\
\text { su „Ryanier“, arba žino, kad reikia pasidaryti, bet } \\
\text { nepagalvoja, kad būtina atsispausdinti, tai ir moka } \\
\text { baudas oro uoste paskui“. } \\
\text { „Pirko žmogus bilietą ị Pekiną per Maskvą, o Maskvoje } \\
\text { persėdimas kitam oro uoste pasirodo, būtų ne per } \\
\text { internetą pirkęs būčiau pasakiusi, kad, jei be vizos } \\
\text { nori, persėdimas tik tam pačiam oro uoste galimas, kai } \\
\text { tranzito zona yra“. }\end{array}$ \\
\hline \multicolumn{2}{|c|}{ Pasiekiamumas } & $\begin{array}{l}\text { „Ne visada prisiskambinsi naktị ị kokios } \\
\text { aviakompanijos ar keltų aptarnavimo centrą, o } \\
\text { paskambinus mums galime ir naktį kokią pavardę } \\
\text { pakeisti ar kelte autobusą ị kitą pakeisti“. }\end{array}$ \\
\hline
\end{tabular}

Išanalizavus tyrimo metu gautus duomenis matyti, informantų teigimu, kad žmogiškasis veiksnys yra esminis kelionių agentūrų privalumas konkuruojant su internetiniais portalais. Turizmo ekspertai išskiria profesionalią asmeninę konsultaciją, kliento laiko taupymą, tiesioginį bendravimą, kai įspūdžiais ir patirtimi dalijasi tiek darbuotojas, tiek klientas. Informantų teigimu, klientams sukuriamas saugumo jausmas, kai įmonei atstovauja konkretus žmogus, su kuriuo bet kada galima susisiekti.

Dauguma informantų teigia, kad kelionių agentūros tam tikrais atvejais klientams gali pasiūlyti žemesnes kainas nei internetiniai portalai bei platesni paslaugų spektrą, kartu pripažistama, kad atsitinka ir atvirkščiai, kai internete pasirinkimas yra didesnis.

Technines kelionių agentūrų galimybes daugelis informantų ịvardijo kaip dar vieną svarbų pranašumą. Galimybè atlikti laikinus lèktuvo bilietų ar keltų užsakymus klientams garantuoja rezervavimo metu turètą kainą, nes taip išsaugomos vietos lèktuve ar kelte. Galimybė po kelių dienų patvirtinti arba atšaukti užsakymą taip pat yra reikšmingas privalumas, kuriantis pridètinę vertę vartotojams. Specializuotų paslaugų užsakymas, tokių kaip vaiko palyda ar vežimèlis neįgaliems asmenims, yra tradicinių kelionių agentūrų išskirtinis privalumas. 
Keli informantai teigè galintys pasiūlyti lankstesnes apmokejjimo sąlygas, kai klientams leidžiama apmokèti grynais pinigais, bankiniu pavedimu ar kortele. Lojaliems verslo ir privatiems klientams gali būti pritaikytas kelias savaites siekiantis apmokèjimo už suteiktas paslaugas atidèjimas.

Daugelis turizmo ekspertų negalèjo įvardyti jokio teikiamų paslaugų išskirtinumo, kuris atsispindètų jų ịmonès internetinèje svetainejje. Informantų teigimu, jų agentūrų internetinėse svetainėse surašytos visos paslaugos, kurias teikia ịmonè, skiriasi tik kiekvieno puslapio dizainas, funkcionalumas, informacijos išdèstymas, kiti kokybiniai parametrai. Išanalizavus informantų atsakymus matoma tendencija teikiamų paslaugų išskirtinumą internetinèje svetainèje sieti su paties tinklalapio išskirtinumu. Daugelis ekspertų išskiria savo puslapyje pateikiamus naujausius pasiūlymus, aktualią informaciją, puslapio paprastumą, funkcionalumą, galimybę užsisakyti internetu.

\section{Diskusijos}

Atlikta literatūros analizè ir tyrimas leidžia teigti, kad kelionių agentūroms kyla rimtų iššūkių, kurie verčia greitai prisitaikyti prie pasikeitusių rinkos sąlygų.

5 lentele. Kelionių agentūrų poveikio veiksniai ir vadybinis atsakas

Table 5. Impact factors for travel agencies and managerial response

\begin{tabular}{|c|c|c|}
\hline Poveikio veiksniai & Rezultatas & Vadybinis atsakas \\
\hline Interneto ịtaka & \multirow{12}{*}{$\begin{array}{l}\text { Klientú skaičiaus } \\
\text { mažèjimas } \\
\text { Pelno maržos } \\
\text { mažejimas }\end{array}$} & Personalo skaičiaus didinimas \\
\hline Vartotojų elgsenos pokyčiai & & Prekès ženklo garsinimas \\
\hline $\begin{array}{l}\text { Išstūmimas iš tarpininkų } \\
\text { vaidmens }\end{array}$ & & Orientavimasis ị verslo segmentą \\
\hline \multirow{4}{*}{$\begin{array}{l}\text { Neigiamas ivaaizdis } \\
\text { Bankrotai } \\
\text { Kainos } \\
\text { Niveliacija }\end{array}$} & & Išskirtinumo siekimas \\
\hline & & Naujausių technologijų isigijimas \\
\hline & & Socialinių tinklų išnaudojimas \\
\hline & & Personalo mokymas \\
\hline \multirow{3}{*}{$\begin{array}{l}\text { Rinkos dalyvių konkurencija } \\
\text { Su tradicinemis agentūromis } \\
\text { Su internetiniais portalais }\end{array}$} & & Pasiekiamumo didinimas \\
\hline & & Internetinio puslapio tobulinimas \\
\hline & & $\begin{array}{l}\text { Popardaviminès komunikacijos } \\
\text { taikymas }\end{array}$ \\
\hline Personalo trūkumas & & \multirow[t]{2}{*}{ Paslaugų plètimas } \\
\hline Geopolitinè situacija & & \\
\hline
\end{tabular}

Kelionių agentūrų, kaip tarpinės grandies, išmetimas iš pardavimo kanalų sistemos bei su tuo glaudžiai susiję vartotojų elgsenos pokyčiai ịvardijami kaip 
didžiausią grèsmę keliantys veiksniai. Šie tyrimo metu gauti rezultatai sutampa su analizuotų mokslinių straipsnių tyrimo rezultatais, kuriuose teigiama apie grèsmès pobūdị: internetas bei naujosios informacinès technologijos kelią reikšmingą grèsmę kelionių agentūrų verslui (Vasudavan, Standing, 1999). Siekdamos išlikti kelionių agentūros turi prisitaikyti prie pasikeitusių sąlygų ir internetą išnaudoti kaip galimybę kurti pridètinę vertę (Kenith Leung, Wong, 2004).

Tyrimo metu nustatyta, kad vartotojų sąmonèje ịsitvirtinęs neigiamas kelionių agentūrų ịvaizdis nulemtas plačiai žiniasklaidos nušviečiamų bankroto atvejų, internetinių turizmo portalų eskaluojamo kainų pranašumo, lyginant su tradicinėmis agentūromis, bei nesugebejimo išsiskirti rinkoje savo teikiamomis paslaugomis ir aptarnavimo kokybe. L. Lawton ir D. Weaver (2009), atlikę tyrimą apie kelionių agentūroms kylančias grèsmes, gavo panašius duomenis. Be to, straipsnio autoriai nustatè, kad prie neigiamo agentūrų ịvaizdžio prisideda nekvalifikuotas personalas ir įmonių nesugebejjimas pritraukti jaunus darbuotojus.

Nors kvalifikuoto personalo trūkumo problema minèta, tačiau ji nèra esminė. Atlikus tyrimą nustatyta, kad šią problemą daugelis kelionių agentūrų stengiasi ịveikti keldami personalo kvalifikaciją ir siūlydami patrauklias darbo sąlygas. Kartu paaiškejjo, kad dalis tyrime dalyvavusių agentūrų neturi aiškios vizijos ir strategijos dèl personalo.

Atlikus tyrimą nustatyta, kad ịtakos sẻkmingai kelionių agentūrų veiklai turi ir geopolitinè situacija, tačiau išanalizavus visų informantų atsakymus galima teigti, kad tai šalutinis, nedominuojantis veiksnys. Savo moksliniame straipsnyje "Travel Agency Threats and Opportunities: The Perspective of Successful Owners" (2009) L. Lawton, D. Weaver mini geopolitinę situaciją, jų teigimu, prie to prisideda ir didelis žiniasklaidos dèmesys šiai temai.

İvertinus bendrą pasisakymų skaičių galima teigti, kad žmogiškasis veiksnys yra esminis ir reikšmingiausias kelionių agentūrų pranašumas, lyginant su internete veikiančiomis kelionių agentūromis. Ši veiksni akcentavo visos be išimties tyrime dalyvavusios agentūros, kurių teigimu, pridètinė vertẻ sukuriama bendraujant tiesiogiai ir dalijantis asmenine patirtimi, teikiant profesionalias asmenines konsultacijas, taupant kliento laiką ir suteikiant galimybę susisiekti ne darbo metu. Minètuose moksliniuose tyrimuose žmogiškasis veiksnys taip pat išskiriamas kaip esminis kelionių agentūrų privalumas. Pirkdamas kelionių agentūroje klientas patiria išskirtinị dèmesị ir gauna profesionalią konsultaciją, kurios negali suteikti internetinis puslapis (Stević, Stevic, 2011). Klientui asmeniškai pritaikytos paslaugos ir pasitikejjimas agentu kuria kelionių agentūrų pridètinę vertę (Carlos, GarciaAgreda, Belén, 2015). 


\section{Išvados}

1. Mokslinès literatūros analizè ir tyrimu gauti duomenys leidžia daryti išvadą, kad kelionių agentūrų veiklai didžiausią poveikị daro du išorès veiksniai: internetas ir naujosios informacinès technologijos bei keleivinio oro transporto dereguliacija. Internetas suteikè galimybę tiekejjams parduoti savo paslaugas tiesiogiai vartotojams, taip agentūras išstumiant iš tarpininkų vaidmens. Panašūs procesai vyko ir dèl dereguliacijos. Be išorès veiksnių, rinką veikè vidiniai kelionių agentūrų rinkos procesai: didelę ịtaką įmonių veiklai darè visuomenèje susiformavęs neigiamas kelionių agentūrų ịvaizdis, prie kurio formavimo daug prisidèjo žiniasklaidoje plačiai nušviesti bankroto atvejai, internetinių turizmo portalų eskaluojamas kainų pranašumas, lyginant su tradicinėmis agentūromis, bei nesugebẻjimas išsiskirti savo paslaugomis iš kitų rinkos dalyvių.

2. Nauji rinkos kaitos veiksniai tiesiogiai paveikẻ kelionių agentūrų veiklą ir vadybą. Informantų teigimu, tradicinès kelionių agentūros prarado nemažai klientų, nes dalis jų paslaugas užsisako internetu. Sumažèjo ir agentūrų pelno marža, nes vyksta intensyvi konkurencija su tiekejjais, kurie siūlo savo paslaugas pirkti tiesiogiai internetu, tradicinèmis ir interneto pagrindu veikiančiomis kelionių agentūromis. Kartu su interneto plètra keičiasi ir vartotojų elgsena, kai savarankiškas turizmo paslaugų užsakymas internetu tampa mados ir saviraiškos forma.

3. Išanalizavus tyrimo metu gautus duomenis pastebèta, kad siekdamos išlikti rinkoje absoliuti dauguma tyrime dalyvavusių agentūrų plečia savo paslaugų spektrą ir aktyviai taiko popardaviminę komunikaciją su klientais. Galima teigti, kad internetas suteiké naujų rinkodaros strategijų igyvendinimo galimybių, atsirado naujų techninių galimybių, kurios supaprastino daugeli techninių procesų, taip sutaupydamos agentūroms laiko ir lèšų. Siekdamos įtvirtinti savo pozicijas rinkoje, didžioji dalis tyrime dalyvavusių agentūrų aktyviai dirba su socialiniais tinklais, suteikia galimybę susisiekti ne darbo metu, investuoja ị interneto svetaines ir informacines technologijas. Išskirtinumo siekimas, prekès ženklo garsinimas, darbas su verslo segmentu ir darbuotojų skaičiaus didinimas pasirinkti tik kelių tyrime dalyvavusių agentūrų.

Gauta 20151130

Pasirašyta spaudai 20160307 
Aušrinė Armaitienė, Daumantas Bočkus

\section{Literatūra}

Armaitiene, A., Bertuzyte, R. (2014). Tourism policy in Lithuania: management of permanent transition. European tourism planning and organisation systems. The EU member states. Ed. by C. Coasta, E. Panyik, D. Buhalis, p. 131-147.

Bergin-Seers, S., O’Mahony, B., Quiazon, R. (2007). The travel agency service industry: industry trends and practices. Sustainable Tourism CRC, p. 1-18.

Costa, J. (1995). International perspectives on travel and tourism development. International Journal of Contemporary Hospitality Management. Vol. 7, No. 7, p. 10-19.

Dixit, M., Belwal, R., Singh, G. (2006). Online Tourism and Travel - Analysing Trends from Marketing Perspective. Prieiga internete: https://www.academia.edu/567058 [žiūrèta 201501 12].

Dodu Silvia, P. (2008). The Internet, Threat or Tool for Travel Agencies. Annals of the University of Oradea. Economic Science Series, Vol. 17, No. 2, p. 106-111.

Kenith Leung, R. L., Wong, J. (2004). The impact of the Internet on travel agencies. International Journal of Contemporary Hospitality Management, Vol. 16, No. 2, p. 100-107.

Law, R., Leung, R., Buhalis, D. (2009). Information Technology Applications in Hospitality and Tourism: a Review of Publications from 2005 to 2007. Journal of Travel \& Tourism Marketing, Vol. 26 (5-6), p. 599-623.

Lawton, L. J., Weaver, D. B. (2009). Travel Agency Threats and Opportunities: The Perspective of Successful Owners. International Journal of Hospitality \& Tourism Administration, Vol. 10, No. 1, p. 68-92.

Lietuvos ekonomikos apžvalga. (2015). Ūkio ministerija.

Mayr, T., Zins, A. H. (2009). Acceptance of Online vs. Traditional Travel Agencies. An International Journal of Tourism and Hospitality Research, Vol. 20 (1), p. 164-177. Anatolia.

Siebenaler, C., Groves, D. L. (2002). Travel Agents and Their Survival. Journal of Human Resources in Hospitality \& Tourism, Vol. 1, No. 1, p. 1-16.

Sor, H. R. D. (2006). Population ecology, institutionalism and the internet. Journal of Organizational Change Management, Vol. 19, No. 2, p. 104-118.

Stević, S. R., Stevic, I. (2011). Challenges for the survival of travel agencies due to new tendencies on the tourism market. Prieiga internete: https://www.academia.edu/3507917 [žiūrèta 201501 10].

Subačienè, R., Senkus, K. (2013). Net Profitability Analysis of Travel Organizers and Travel Agencies. Ekonomika, Vol. 92(1), p. 156-165.

Vasudavan, T., Standing, C. (1999). The impact of the Internet on the role of travel consultants. Participation and Empowerment: an International Journal, Vol. 7, No. 8, p. 213-226.

Carlos, D., Garcia-Agreda, S., Belén, R. N. (2015). The Value of Trust for Travel Agencies in Achieving Customers’ Attitudinal Loyalty. Journal of Promotion Management, Vol. 21, Issue 4, p. 516-529.

\section{BUSINESS MARKET CHANGE FACTORS OF TRAVEL AGENCIES IN LITHUANIA}

\section{Aušrinė Armaitienė, Daumantas Bočkus}

\section{Summary}

Tourism is the world's largest civilian industry whose growth, economic significance and potential are phenomenal across the globe (Dixit, Belwal, Singh, 2006). Lithuania is entering the European tourism market - an established market that is, however, experiencing permanent changes due to market liberalization, climate 
change, and economic crisis - under conditions of fierce competition (Armaitienè, Bertužytè, 2014).

The tourism sector includes the activity of travel organizers and travel agencies which embrace all tourism functions, forms and products, and reflect its tendencies. The tourism sector is one of the most important spheres of research as it is one of the most promising branche of industry in Lithuania and a good indicator of economic changes (Subačienè, Senkus, 2013).

According to the Ministry of Economy of the Republic of Lithuania, GDP from tourism sector in 2015 made $3 \%$. World Travel \& Tourism Council estimates that tourism sector input to general GDP could be about $4.8 \%$, if indirect impact of tourism was considered. Tourism and related sectors employs 41.1 thousand people which makes $4.4 \%$ of total employees in Lithuania (Lithuanian economy review, 2015).

Awareness of market change factors are essential for travel agencies seeking to remain in the business. The change of travel agency business model, technological progress, rapid spread of the Internet and other fundamental changes create new challenges for travel agency business market. Customers eliminate travel agencies by planning and booking holidays or business themselves. Internet booking by travelers has grown and will most likely continue to grow with the spread of other technologies. Furthermore, ticket-less travel using smart (computer chip imbedded) credit cards or e-tickets is also a key factor influencing electronic based purchasing by travelers (Bergin-Seers, O'Mahony, Quiazon, 2007).

A rapid and evident development of the tourism sector attracts considerable attention from researchers. The impact of the Internet on the role of travel consultants is examined by Vasudavan and Standing (1999). The study showed that there is an expected decrease of travel agencies in the market. A significant part of travel agency threats is linked with the spread of the Internet and the development of information technologies (Law, Leung, Wong, 2004; Mayr, Zins, 2009; Dixit, 2001; Dodu Silvia, 2008) Siebenaler and Groves (2002) emphasize that the success of travel agency survival depends on successful adaptation of e-commerce. Negative mass media coverage is also one of the key problems for travel agencies (Lawton, Weaver, 2009). A study carried out by Bergin-Seers, O’Mahony, Quiazon (2007) indicates that internet has caused the change of booking model and the change of information retrieval channel. Information technology and the Internet determined new rules that set the conditions within which organizations can operate, and management can make strategic choices. Only those organizations, which have an inherent variation to adjust to the new conditions, will be selected to survive (Sor, 2005). 
The analysis of the article shows that the authors of travel agency business and management studies used traditional sociological methods: interviews and expert evaluation method, questionnaires, content analysis and case studies.

Nevertheless, the market change factors on Lithuanian travel agency business have not been thoroughly analysed. Travel agency business sector is usually studied through marketing, and consumer behavior research context without any emphasis on the market change factors.

Preliminary studies indicate that travel agencies business conditions are getting complicated. This may be related to certain problematic factors: the development of information technologies, increased competition, and loss of market share or profit margins. The research object - the impact of market change factors on $\mathrm{Li}$ thuanian travel agency business. The aim of the research presented in the article is to analyse the factors that shape and induce the change in travel agency business market. To achieve the indicated aim the following objectives were set:

- To analyse the market change factors in Lithuanian travel agency business;

- To explore the impact of the Internet on travel agency market;

- To analyse the managerial response adapted by enterprises to resist the impact of factors.

Qualitative research was carried out by applying in-depth interview method. Research involved experts selected according to the size of the agency. C. Siebenaler and D. L. Groves article "Travel agents and their survival" (2002) divides travel agencies into four categories: 1) independent operator of a small travel agency with very limited resources; 2) normal agency with 2 or 3 agents which does a substantial business; 3) larger agency that is high-tech and high touch and depends on automation and the Web to some extent (innovators); 4) agencies that are Web based. During the study carried out in Lithuania the second and third categories were used. Experts were considered to be professionals with at least 5 years of experience in travel agency. The material obtained during the interviews with tourism experts was transcribed and analysed by applying qualitative research criteria.

Lithuanian travel agency expert study, carried out in 2015, showed that travel agencies are challenged by intense change of market factors. The Internet and development of information technologies were identified as most significant factors. Travel agency threats are linked with a process of disintermediation, when suppliers sell directly to customers eliminating travel agencies from the distribution chain. Another challenge is negative public perception that is caused by negative references about agencies in the mass media. It publishes bankruptcy cases and escalates online travel agencies price advantage over conventional agencies. Ina- 
bility to distinguish their services from other market participants could also be considered. Geopolitical situation, and lack of professional employees were also mentioned but that could be seen as minor factors.

According to the travel experts, the spread of the Internet and development of information technologies resulted in decreased number of customers and lower margin of profit. Informants stated that it is caused by intense competition with other online and conventional travel agencies as well as with suppliers that are selling directly to customers. Another reason for this process is the change of customer behavior, when self-service booking became a form of fashion and expression of individuality.

The analysis of the research data shows that the Internet facilitated access to customers and provided new opportunities for marketing campaigns. New information technology systems provided wider accessibility to different tourism services and products worldwide and the process of booking became instant and more effective.

In addition, the analysis of the research data shows that the human factor is essential and is the most significant advantage of the conventional travel agencies over the internet based travel agencies. This factor was emphasized by all agencies involved in the investigation, claiming that direct communication, sharing personal experience, providing professional personal advice, saving customer's time and possibility to contact the agent after working gives important added value.

Technical features, price, amount of services and payment conditions could be seen as advantages or disadvantages over the online based travel agencies as it varies depending on situation and specific service.

Research data shows that travel agencies are trying to respond to emerging challenges by expanding the amount of services provided, implementing aftersales communication, giving the opportunity to contact after working hours, investing in website, technologies and social networks. Increasing the number of employees, investing in brand creation or working with corporate clients are not considered to be popular methods while seeking to fight emerging challenges.

\section{Conclusions}

1. Analysis of the scientific literature and the research findings lead to the conclusion that there are two principal external factors that made the most significant impact on travel agency market: the Internet and new information technologies and deregulation of passenger air transport. Suppliers benefitted from the Internet emergence and embraced the opportunity to sell their products directly to customers that lead to disintermediation of 
travel agents. Similar impact was also induced by the deregulation of air transport. In addition to external factors, the market have been affected by the internal processes of travel agency market: negative public perception is considered to be caused by negative references about agencies in the mass media where bankruptcy cases are published, as well as escalation of online travel agencies price advantage over conventional agencies and the inability to distinguish their services from other market participants.

2. Management and operation of travel agencies were directly influenced by new market change factors. According to the informants, conventional travel agencies lost a large amount of customers as a part of them switched to online booking. Intense competition with suppliers who sell directly online, as well as competition with conventional and internet based travel agencies, lead to decreased profit margins. Expansion of the Internet is related to the changed consumer behavior when self-service online booking of tourism products became a form of expression and fashion.

3. The analysis of the research data shows that in order to survive in the market most of the agencies are expanding their range of services and employing the after sale communication with customers. The article identifies that the Internet has created new opportunities for marketing strategies. Moreover, new technical possibilities emerged, which simplified a number of technical processes that saves time and financial resources. In order to enhance the position in the market, the majority of the surveyed agencies work with social networks, provide an opportunity to contact after working hours, invest in the website and information technology. Only a few agencies were seeking for exclusivity, increasing the number of staff, working on brand prominence or dealing with corporate clients. 